\title{
Pengaruh Pendekatan Somatis, Audiotori, Visual Intelektual (Savi) Berbasis Brain Gym Terhadap Hasil Belajar Kognitif Peserta Didik Pada Materi Pencemaran Lingkungan
}

\author{
Rifda El Fiah, Rendy Rinaldy \\ Dosen dan Mahasiswa Fakultas Tarbiyah dan Keguruan, IAIN Raden Intan Lampung
}

Diterima: April 2015. Disetujui: Mei 2015. Dipublikasikan: Juni 2015

\begin{abstract}
Abstrak: Penulis menggunakan metode penelitian eksperimen karena penulis akan mencari pengaruh treatment (perlakuan) tertentu. Jenis eksperiment yang digunakan adalah Quasy Experimental Design yaitu desain ini memiliki kelompok kontrol tetapi tidak berfungsi sepenuhnya untuk mengontrol variabel-variabel luar yang mempengaruhi pelaksanaan eksperimen. Penelitian ini dilakukan di kelas VII SMP Negeri 13 Bandar Lampung yang terdiri dari 2 kelas yakni kelas eksperimen (VII E) yang diterapkan Pendekatan Somatis, Audiotori, Visual, Intelektual (SAVI) berbasis brain gym terhadap hasil belajar kognitif dan kelas kontrol (VII A) menggunakan pembelajaran metode ceramah dan tanya jawab. Teknik pengumpulan data yaitu test (pretest dan postest), dan dokumentasi. Terdapat pengaruh yang signifikan Pendekatan Somatis, Audiotori, Visual, Intelektual (SAVI) berbasis Brain Gym terhadap hasil belajar kognitif dalam pembelajaran IPA khususnya pada siswa SMPN 13 Bandar Lampung. Pencapaian hasil belajar kognitif meningkat dapat di lihat dari nilai pretest dan posttest, pada kelas kontrol rata-rata pretest 63,75 dan posttest 70,63 dan kelas eksperimen rata-rata pretest 69,06 dan posttest 77,03 .
\end{abstract}

Kata Kunci: Pendekatan Somatis, Audiotori, Visual, Intelektual (SAVI) berbasis Brain Gym, Hasil belajar

\section{Pendahuluan}

Perkembangan ilmu pengetahuan dan teknologi yang semakin pesat dewasa ini mengakibatkan suatu perubahan disegala bidang, tak terkecuali bidang pendidikan. Pendidikan merupakan instrumen yang sangat amat penting bagi setiap bangsa untuk meningkatkan daya saingnya dalam bidang ekonomi, hukum, budidaya dan pertahanan pada tata kehidupan masyarakat dunia global. Sadar akan hal seperti itu negara maju sekalipun selalu membangun dunia pendidikan tanpa henti- hentinya.

Menurut Oemar Malik, pendidikan adalah suatu proses dalam rangka mempengaruhi peserta didik supaya mampu mennyesuaikan diri sebaik mugkin dengan lingkungannya, dan dengan demikian akan menimbulkan perubahan dalam dirinya yang memungkinkan untuk berfungsi secara dekat dalam kehidupan masyarakat. (Oemar Malik, 2008) Hal ini sesuai dengan undang-undang RI nomor 20 tahun 2003 tentang sistem pendidikan Bab 1 pasal 1 (1) pendidikan di defenisikan sebagai usaha sadar dan terencana untuk mengwujudkan suasana belajar dan proses belajar agar peserta didik secara aktif mengembangkan potensi diri untuk meningkatkan spiritual keagamaan, Pengendalian diri, kepribadian, kecerdasan, akhlak mulia, serta keterampilan yang diperlukan dirinya, masyarakat, bangsa dan negara. (Syah, 2012 )

Berdasarkan pendapat diatas maka pendidikan mempunyai pengaruh yang sangat luar biasa dalam kehidupan manusia. dari sudut pandang manusia pun seeorang yang berpendidikan mendapatkan derajat yang lebih tinggi daripada yang tidak berpendidikan.

Pembelajaran merupakan bantuan yang diberikan pendidik agar dapat terjadi proses pemerolehan ilmu dan pengetahuan, penguasaan kemahiran dan tabiat, serta pembentukan sikap dan kepercayaan pada peserta didik (pembelajaran). Dengan kata lain, pembelajaran adalah proses untuk membentuk peserta didik agar dapat belajar dengan baik. Proses pembelajaran dialami manusia sepanjang hayat, serta berlaku di mana pun dan kapan pun (Rahyubi, 2012) 
Menuntut ilmu yang dimaksud adalah ilmu yang bermanfaat bagi dirinya dan bagi orang lain dan tidak merugikan orang lain, salah satu ilmu tersebut ialah ilmu mengenai Pelajaran IPA. Biologi merupakan bagian dari sains yang mempelajari tentang makhluk hidup dan lingkungannya. Biologi sebagai bagian dari sains terdiri dari aspek produk, proses, dan sikap. Aspek produk biologi terdiri atas fakta, konsep, prinsip, dan teori yang berkaitan dengan kehidupan makhluk hidup beserta interaksi dengan lingkungannya. Aspek proses adalah proses yang digunakan untuk menemukan produk sains. Aspek proses biologi berupa keterampilan proses sains meliputi aspek mengamati dengan indera, mengelompokkan, menerapkan konsep atau prinsip, menggunakan alat dan bahan, berkomunikasi, merumuskan hipotesis, menafsirkan data, melakukan percobaan, dan mengajukan pertanyaan. Sikap adalah karakter ilmiah yang muncul setelah siswa mempelajari IPA. Sikap yang diperoleh berupa sikap jujur, tanggung jawab, dan teliti.

Pembelajaran IPA yang menekankan pada aspek proses menuntut siswa harus belajar secara konstruktivisme untuk membangun konsep IPA secara mandiri. Konsep yang ditemukan secara mandiri akan membuat siswa lebih paham dan mengingat materi lebih lama dibandingkan dengan sekedar menghafal konsep. Menemukan konsep pada pembelajaran IPA membuat siswa lebih aktif tanpa harus bergantung pada guru. Pembelajaran yang seperti ini tentu akan menghasilkan prestasi belajar yang lebih maksimal dan efektif dibandingkan pembelajaran IPA yang hanya mengacu pada aspek produk. Menurut Laksmi prihantoro dkk, mengatakan bahwa IPA hakikatnya merupakan suatu produk, proses dan aplikasi. Sebagai produk, yang merupakan sekumpulan pengetahuan dan sekumpulan konsep dan bagan konsep. sebagai proses ,IPA merupakan proses yang dipergunakan untuk mempelajari objek studi, menemukan dan mengembangkan produk-produk sains, dan sebagai aplikasi,teori-teori IPA akan melahirkan teknologi yang dapat member kemudahan kehidupan. (Trianto, 2012) Berdasarkan hasil wawancara di SMPN 13 Bandar Lampung, pembelajaran IPA di SMPN 13 Bandar Lampung masih terorientasi pada aspek produk, cara belajar siswa yang lebih menekankan untuk menghafal daripada berusaha untuk menemukan konsep IPA, dan siswa kurang aktif dalam pembelajaran IPA. Permasalahan ini terjadi karena adanya kecenderungan seorang guru yang menganggap bahwa biologi hanya teori dan kumpulan produk sains sehingga cenderung membuat siswa untuk menghafal materi. Hal ini dapat terlihat dari nilai ulangan harian belajar kognitif peserta didik.

Hasil belajar sangat dipengaruhi oleh pemilihan model pembelajaran. Oleh karena itu guru mampu menawarkan metode dalam mengajar yang lebih efektif yang dapat membangkitkan perhatian peserta didik sehingga menampakkan hasil yang maksimal dalam penacapaian hasil belajar peserta didik. Peneliti mencoba meberikan solusi khususnya dalam pembelajaran IPA dengan menggunakan pendekatan Somatis, Audiotori, Visual dan Intelektual (SAVI) Berbasis Brain Gym. Unsur - unsur pendekatan SAVI adalah:

1. Somatis (S) : Belajar bergerak dan berbuat

2. Auditori (A) : Belajar dengan berbicara dan mendengarkan

3. Visuak (V) : Belajar dengan mengamati dan menggambar

4. Intelektual (I) : Belajar dengan memecahkan masalah dan merenung (Meier, 2002).

Pembelajaran IPA pendekatan SAVI biasa optimal jika keempat unsur SAVI ada dalam satu peristiwa pembelajaran IPA. Misalnya peserta didik akan belajar sedikit tentang biologi, dengan menyaksiakan persentasi (V), tetapi mereka dapat dapat belajar banyak jika mereka melakukan sesuatu (S),membicarakan atau mendiskusikan apa yang mereka pelajari (A), serta memikirkan dan mengambil kesimpulan atau informasi-informasi yang mereka peroleh untuk diterapkan dalam menyelesaikan soal-soal (I) atau, peserta didik dapat meningkatkan kemampuan mereka dalam mengemukakan ide (I), jika mereka secara simultan menggerakan sesuatu (S) sambil mendidiskusikan atau membicarakan apa yang sedang mereka kerjakan (A). Berdasarkan 
uraian diatas, maka penulis tertarik mengkaji suatu model yang dapat digunakan dalam pembelajaran IPA.

\section{Metode Penelitian}

Penentuan sampel dilakukan dengan metode purposive sampling yaitu penentuan sampel berdasarkan pertimbangan. (Sudjana, 2005) Dalam penelitian ini pengambilan dua kelas yaitu kelas VII E sebagai kelas eksperimen berjumlah 32 peserta didik dan kelas VII A sebagai kelas kontrol berjumlah 32 peserta didik, dilakukan secara purposive dengan pertimbangan bahwa seluruh kelas VII pada saat pembentukannya terdiri dari berbagai macam karakter siswa tanpa ada penggolongan kelas khusus sehingga kelas-kelas bersifat heterogen dan dalam pemilihannya berdasarkan pertimbangan dari guru. Populasi dalam penelitian ini adalah seluruh peserta didik kelas VII SMP N 13 Bandar lampung tahun pelajaran 2014/2015. Jenis penelitian yang digunakan dalam penelitian ini adalah penelitian eksperimen.

Metode penelitian eksperimen dapat diartikan sebagai metode penelitian yang digunakan untuk mencari pengaruh perlakuan tertentu terhadap yang lain dalam kondisi yang terkendalikan. (Sugiyono, 2009) Penulis menggunakan metode penelitian eksperimen karena penulis akan mencari pengaruh treatment (perlakuan) tertentu. Jenis eksperiment yang digunakan adalah Quasy Experimental Design yaitu desain ini memiliki kelompok kontrol tetapi tidak berfungsi sepenuhnya untuk mengontrol variabel-variabel luar yang mempengaruhi pelaksanaan eksperimen.

\section{Hasil Dan Pembahasan}

Data yang digunakan dalam penilitian yaitu tes berupa nilai pretest dan posttest. Data tersebut digunakan untuk mengetahui hasil belajar. Kelas yang di gunakan pada saat penelitian 2 kelas yaitu kelas VII E sebagai kelas eksperimen dan kelas VII A sebagai kelas kontrol. Setelah dilakukan penelitian sesuai dengan prosedur dan teknik yang telah ditentukan sebelumnya, maka disajikan data hasil penelitian sebagai berikut:

Dalam proses pembelajaran yang menggunakan pendekatan SAVI (Somatis, Audiontori, Visual, Intelektual) berbasis Brain Gym atau kelas eksperimen dimulai dengan pemberian pretest, kemudian siswa di hadapkan dengan permasalahan yang berkaitan dengan pencemaran lingkungan, dan siswa berpartisipasi mencari solusi dari permaslahan tersebut lalu di akhiri dengan posttest. Hal ini dilakukan untuk mengukur penguasaan pada materi pokok pencemaran lingkungan. Adapun perolehan dari pretest dan posttest siswa dapat dilihat pada table berikut:

\begin{tabular}{cll} 
Tabel 1. Skor Hasil Belajar IPA Kelompok Eksperimen \\
\cline { 2 - 3 } & Pretest & Posttest \\
\hline Nilai tertinggi & 85 & 95 \\
Nilai terendah & 50 & 60 \\
Jumlah & 2220 & 2525 \\
Rata-rata & 69,38 & 78,91 \\
\hline
\end{tabular}

Dari tabel diatas diperoleh hasil pretest dan posttest pada kelas eksperimen yaitu: Pada nilai pretest nilai yang diperoleh adalah 85 dan pada nilai posttest adalah 95. Sedangkan hasil pretest nilai terendah yang diperoleh adalah 50 dan pada nilai posttest adalah 60 . Jumlah keseluruhan dari nilai pretest pada kelas eksperimen adalah 2220 dan nilai posttest adalah 2525. Sehingga rata-rata nilai pretest yang diperoleh pada kelas eksperimen yaitu 69,38 dan nilai posttest adalah 78,91.

Pada kelas yang tanpa menggunakan pendekatan SAVI (Somatis, Audiontori, Visual, Intelektual) berbasis Brain Gym atau kelas kontol dimulai dengan pemberian pretest, kemudian 
guru menggunakan metode ceramah, Tanya jawab dan diskusi kemudian diakhiri dengan guru memberikan posttest. Hal ini dilakukan juga untuk memperoleh data pretest dan posttest. Adapun nilai hasil dari pretest dan posttest dapat dilihat pada tabel berikut:

\begin{tabular}{lcc} 
Tabel 2. Skor Hasil Belajar Kelompok Kontrol \\
\hline & Pretest & Posttest \\
\hline Nilai tertinggi & 80 & 85 \\
Nilai terendah & 50 & 55 \\
Jumlah & 2040 & 2290 \\
Rata-rata & 63,75 & 71,56 \\
\hline
\end{tabular}

Dari table diatas diperoleh hasil pretest dan posttest pada kelas kontrol yaitu: Pada nilai pretest nilai yang diperoleh adalah 80 dan pada nilai posttest adalah 85 . Sedangkan hasil pretest nilai terendah yang diperoleh adalah 50 dan pada nilai posttest adalah 55. Jumlah keseluruhan dari nilai pretest pada kelas kontrol adalah 2040 dan nilai posttest adalah 2290. Sehingga ratarata nilai pretest yang diperoleh pada kelas eksperimen yaitu 63,75 dan nilai posttest adalah 71,56 .

Hasil normalitas dan homogenitas untuk pretest untuk pretest dan posttest dapat dilihat pada table berikut:

\begin{tabular}{ccccc}
\multicolumn{4}{c}{ Tabel 3. Hasil Normalitas dan Homogenitas Pretest } \\
\hline Karakteristik & $\begin{array}{c}\text { Kelas } \\
\text { Kontrol }\end{array}$ & $\begin{array}{c}\text { Kelas } \\
\text { Eksperimen }\end{array}$ & Hasil & Interprestasi \\
\hline LHitung & 0.137 & 0.142 & $\begin{array}{c}\text { LHitung }< \\
\text { LTabel }\end{array}$ & $\begin{array}{c}\text { Berdistribusi } \\
\text { Normal }\end{array}$ \\
LTabel & 0.150 & 0.150 & & \\
FHitung & & 1.414 & FHitung $<$ & Homogen \\
& & 1.822 & FTabel & \\
FTabel & & & 62 & \\
Db & & & $5 \%(0.05)$ & \\
Taraf Sign & & & &
\end{tabular}

Dari table diatas dieroleh hasil uji normalitas untuk Lhitung tes awal kelas kontrol 0.137 dan Lhitung kelas eksperimen 0.142 sedangkan Ltabel $=1.822$ dengan demikian kelas kontrol dan kelas eksperimen berdistribusi normal karena Lhitung $<$ LTabel yaitu $0.137<0.150$ dan $0.142<0.150$ pada tes akhir kelas kontrol diperoleh Lhitung 0.133 dan LTabel 0.150 Hal ini menunjukkan bahwa berdasarkan tes akhir kelas kontrol dan kelas eksperimen nasih beristribusi normal karena $0.095<$ 0.150 dan $0.133<0.150$

Hasil homogenitas untuk Fhitung tes awal 1.414 dan Fhitung tes terakhir 1.254 dengan Ftabel 1822 pada taraf nyata 5\% (0.05) dan derajat kebebasan maka Fhitung $<$ Fhitung yaitu $1.414<1.254$ hal ini menunjukkan tidak terdapat perbedaan yang signifikan berarti data tersebut atau homogennya sama, sehingga dapat dilakukan sebagai objek penelitian sekanjutnya.

Berdasarkan hasil analisi dara penelitian diatas, diketahui bahwa sampel berasal dari ditribusi yang normal, dan memiliki varian dan homogennya artinya kedua sampel memiliki kemampuan yang sama sehingga dapat digunakan sebagai sampel penelitian ini.

\section{Simpulan dan Saran}

Berdasarkan dari hasil penelitian, pengolahan data, dan analisis data pada Pengaruh pendekatan somatis, audiotori, visual, intelektual (SAVI) berbasis Brain Gym terhadap hasil belajar kognitif IPA. siswa SMPN 13 Bandar Lampung, maka dapat ditarik kesimpulan sebagai berikut:

Terdapat pengaruh yang signifikan Pendekatan Somatis, Audiotori, Visual, Intelektual (SAVI) berbasis Brain Gym terhadap hasil belajar kognitif dalam pembelajaran IPA khususnya 
pada siswa SMPN 13 Bandar Lampung. Berdasarkan perhitungan, $\mathrm{Db}=62$, thitung $=2,534$ sedangkan ttabel $=1,998$ sehingga thitung $>$ tabel yaitu 2,534 $>1,998$. Jadi dalam hal ini Ho ditolak dan $\mathrm{H}_{1}$ diterima.

Pencapaian hasil belajar siswa pada pelajaran IPA SMPN 13 Bandar Lampung meningkat dapat di lihat dari nilai pretest dan posttest, pada kelas kontrol rata-rata pretest 63,75 dan posttest 70,63 dan kelas eksperimen rata-rata pretest 69,06 dan posttest 77,03.

\section{Daftar Pustaka}

Meier, D. (2002). The Accelerated Learning Hand Book. Bandung: Kaifa.

Oemar Malik. (2008). Kurikilum dam Pembelajaran . Jakarta : PT Bumi aksara.

Rahyubi, H. (2012). Teori-teori Belajar dan Aplikasi Pembelajaran Monotorik Deskripsi dan Tinjauan Kritis. Jawa Barat: Nusa Media.

Sudjana. (2005). Metoda Statistika. Bandung: Tarsito.

Sugiyono. (2009). Metode Penelitian Kuantitatif, Kualitatif, dan R D. Bandung: Alfabeta.

Syah, M. (2012 ). Psikologi Pendidikan. Jakarta: PT Raja grafindo persada.

Trianto. (2012). Model pembelajaran terpadu. Jakarta: Bumi angkasa. 
